\title{
A gépi tanulás szerepe és hatásai a közlekedésben
}

\author{
Napjainkban a közlekedés folyamatos változáson megy keresztül, \\ amely szinte minden részterületét érinti és hatással lesz a jövőre is. \\ Közlekedésszervezési oldalon az új adatgyüjtési technikák soha nem \\ látott lehetőségeket nyitottak meg a forgalombecslés és -irányítás te- \\ rületén.
}

DOI 10.24228/KTSZ.2020.1.1

\section{Bécsi Tamás - Aradi Szilárd - Fehér Árpád}

\author{
BME Közlekedés- és Jármúirányítási Tanszék \\ email: becsi.tamas@mail.bme.hu • aradi.szilard@mail.bme.hu • feher.arpad@mail.bme.hu
}

\section{BEVEZETÉS}

$\mathrm{Az}$ emberek nagy részénél meglévő okoseszközök lehetővé teszik az új innovatív navigációs és útvonaltervező szolgáltatások (1. ábra) kifejlesztését. Ez utóbbiakat már nem is igazán írja le jól a nevük, hiszen ennél jóval összetettebb megoldások jelennek meg, amelyeket az ún. „Mobility as a Service” kifejezés alá sorolhatunk. Ennek során már a felhasználó teljes mobilitási igényeire keressük a válaszokat, beleértve a közlekedési módozatokat, figyelembe véve a különböző optimalizálási kritériumokat (eljutási idő, költség, károsanyag-kibocsátás). Ennek részeként egyre nagyobb teret kapnak a járműmegosztó szolgáltatások, ahol a legkülönbözőbb típusú és kategóriájú járműveket vehetik igénybe a felhasználók a nagyvárosokban, kihasználva az okoseszközök által nyújtott kényelmi szolgáltatásokat.

Jármüipari oldalon két fö területen láthatunk komoly fejlődést. A hajtásláncoknál jelenleg még lassan, de folyamatosan gyorsuló ütemben terjednek az olyan alternatív megoldások, mint a hibrid és elektromos hajtások. Ezt a folyamatot tovább gyorsította a 2015-ben kirobbant „dízelbotrány”, valamint a német szövetségi bíróság 2018. februári ítélete, amely lehetővé teszi az Euro 6-os környezetvédelmi besorolásnál rosszabb dízelüzemű gépjármüvek városokból történő kitiltását.

A másik jelentős tempóban fejlődő terület a vezetéstámogató rendszereké ([1] és [2]), ahol a fejlesztők célja, hogy végül teljesen automatizált jármüvek közlekedjenek az utakon. Ennek elérése érdekében két technológiai terület bevonására van szükség. Az egyik a modern vezeték nélküli infokommunikációs megoldások, a másik pedig a mesterséges intelligencia, azon belül is a gépi tanulás. A hagyományos autógyártók és beszállítóik ezzel a tudással korábban nem rendelkeztek, így mozgástérhez jutottak a nagy nemzetközi IT cégek. Ezek komoly hatással voltak az elmúlt évek fejlesztéseire, amelyek között találunk pozitív és negatív példákat is. Az egyik legjelentősebb fejlesztés a Google önvezető autója, amely Waymo néven jelenleg egy publikus pilot projektet futtat egy teljesen önvezető flottával Arizona állam bizonyos városaiban. 


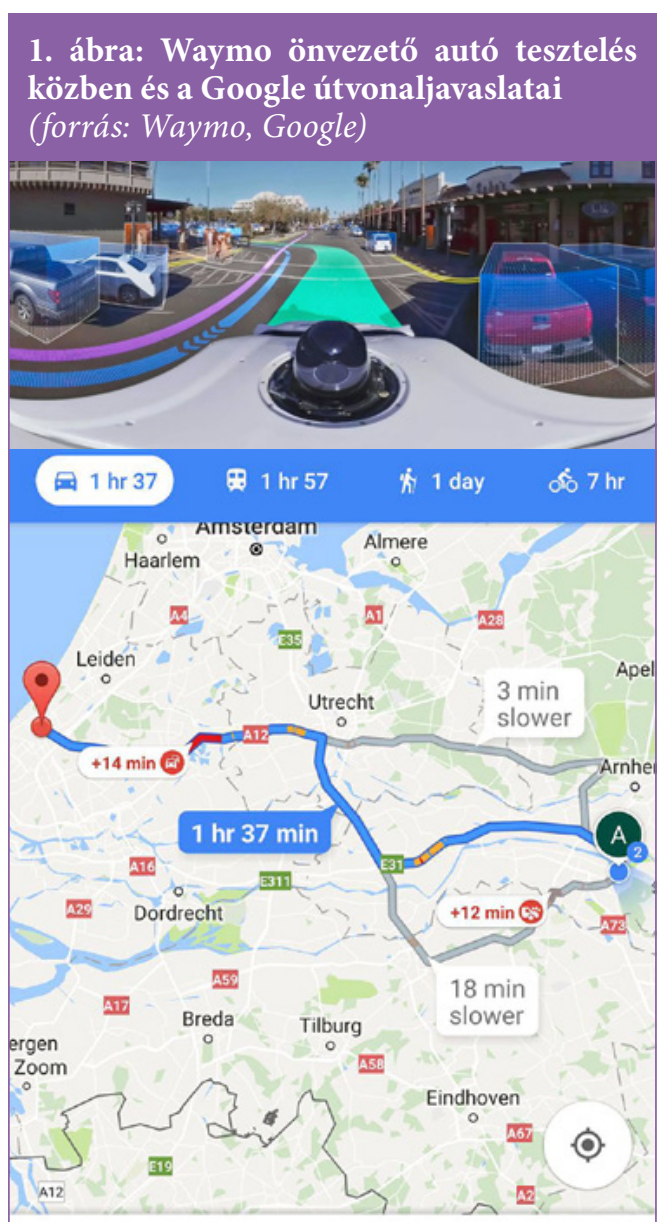

$1 \mathrm{hr} 37 \mathrm{~min}(138 \mathrm{~km})$

Fastest route, despite congestion on A12 causing 14-min delay

A fejlesztők rendkívül komolyan veszik a biztonságot [3] és kellő figyelmet fordítanak mind a virtuális, mind pedig a valós tesztekre. Sajnos negatív tapasztalatokat is találunk az elmúlt évekböl. Az egyik a Tesla Autopilot nevü rendszerével kapcsolatos, amely több halálos kimenetelü balesethez (például [4]) vezetett. Mivel a rendszer 2-es szintü vezetéstámogató rendszer, ezért jogilag a jármüvezető a felelős. A másik szomorú példa az Uber tesztelés alatt álló önvezető járműve - emberi felügyelet mellett - elgázolt egy kerékpárost, aki nem élte túl az ütközést. A téma felkapottsága miatt a fejlesztők minél gyorsabban próbálnak eredményeket felmutatni, és az új szereplők nem mindig követik azokat a biztonsági és teszte- lési eljárásokat, amelyek a hagyományos gyártóknál már beváltak. Mindezek komoly etikai kérdéseket vetnek fel, amelyek veszélyeztethetik az önvezető jármüvek társadalmi elfogadottságát.

Cikkünkben először bevezetjük a mesterséges intelligencia és a gépi tanulás fogalmát. Ezt követően rámutatunk a jogi, etikai és infrastrukturális kérdésekre, és egy rövid kitekintést adunk arról, hogy milyen hatással lehet ez az innovációs szektorra. Végül egy konkrét esettanulmányon keresztül bemutatjuk a gépi tanulás járműirányítási célú felhasználását, amit a ZalaZone tesztpálya segítségével teszteltünk.

\section{MESTERSÉGES INTELLIGENCIA ÉS GÉPI TANULÁS}

Ahogy az előzőekben már említésre került, abban szinte egyhangúak a vélemények, hogy a mesterséges intelligencia alkalmazása a közlekedés területén már ma is megjelent és egyre intenzívebb szerepet fog betölteni, különös tekintettel az önvezető járművekre. A következőkben áttekintjük, hogy ezen belül mely területek adhatnak hatékony megoldásokat a legfontosabb jármüirányítási problémákra.

A mesterséges intelligencia első alapvető fogalma az ágens. Ezen egy olyan algoritmust értünk, amely érzékeli környezetét és autonóm módon cselekszik. A racionális ágens pedig a legjobb (várható) kimenetel érdekében cselekszik [5].

A mesterséges intelligencia rendkívül széles tudományterület, ezen belül napjaink egyik legdinamikusabban fejlődő területe a gépi tanulás. Ennek két fö oka van, amelyek közül az első a számítógépek számítási teljesítményének évtizedek óta tartó exponenciális növekedése, a második pedig az internetnek köszönhető hatalmas mennyiségű adat rendelkezésre állása. Definíció szerint egy számítógépes programról akkor mondjuk, hogy tanul egy E tapasztalatból a T feladat tekintetében, ha a teljesítménynek T-re vonatkozó $\mathrm{P}$ mérőszáma növekszik az E tapasztalattal [6]. 


\section{2. ábra: Példa a többrétegú mesterséges neurális hálózatokra [18]}

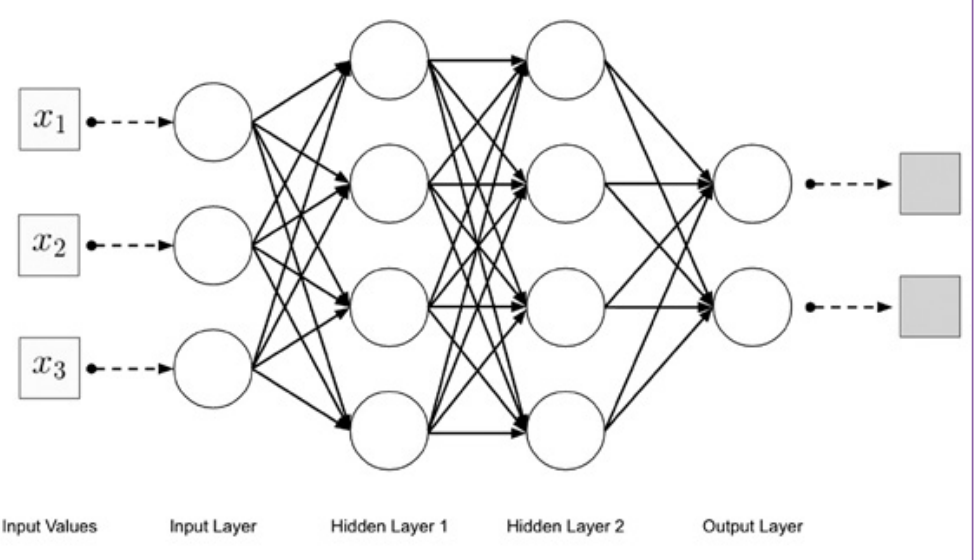

A gépi tanuláson belül három fontos csoportot különböztetünk meg:

- felügyelt tanulás: címkézett adatok segítségével (azaz ismert bemenetekre ismerjük a rendszer válaszát) határozzuk meg a változók közötti függvénykapcsolatot;

- felügyelet nélküli tanulás: következtető függvény elóállítása, amely rejtett struktúrákat ír le címkézetlen adatokból;

- megerősítéses tanulás: az ágens megtanulja, hogy hogyan kell viselkednie egy adott környezetben, hogy a jutalmát maximalizálja.

A gépi tanuláson belül két fontos területet övez intenzív érdeklődés a jármüipar részéről. Az első a mélytanulás vagy a mély mesterséges neurális hálózatok alkalmazása. A mesterséges neuron megalkotása már 1943-ban megtörtént, majd a '60-as években Rosenblatt úttörő munkássága újabb lökést adott a témának [7]. Azonban ezt követően a '80-as évek végéig tetszhalott állapotban maradt. Az új elméleti eredmények mellett az egyre gyorsabb számítógépek is sokat segítettek a téma fellendülésében. Ekkor alakult ki a mélytanulás kifejezés is, amely a 2010-es évektől kezdve már a köztudatba is beszivárgott. A mélytanulás során olyan elörecsatolt neurális hálózatokat alkalmaznak, amelyek a be- és kimeneti rétegek között több rejtett réteget is tartalmaznak. Habár egy elörecsatolt neurális hálózat egy rejtett réteggel (véges számú neuronnal) is képes közelíteni folytonos függvényeket $\mathrm{az}$ $\mathrm{n}$-dimenziós tér $\left(\mathrm{R}_{\mathrm{n}}\right)$ egy kompakt részhalmazán, azonban több rejtett réteggel (2. ábra) ugyanaz a feladat kevesebb neuronnal is megvalósítható [8].

$\mathrm{Az}$ ilyen többrétegű hálózatok kiválóan alkalmasak például klaszszifikációs feladatokra, amikor a címkézett nyers szenzoradatokból betanítható egy objektumfelismerő hálózat. Ilyenkor nincs szükség klasszikus képfeldolgozási lépésekre, ezek maguktól alakulnak ki a hálózat rétegein belül. A járművekben elsősorban képfeldolgozásra használják ezeket a módszereket, amelyek a hálózat bemenete után általában konvolúciós rétegeket helyeznek el. Emellett objektumklasszifikációra alkalmazzák radarjelek feldolgozásánál. Továbbá vannak olyan törekvések is, ahol a nyers szenzorbemenetekből közvetlenül próbálják előállítani a beavatkozó jeleket, ami az ún. „end-to-end-learning” feladatokhoz vezet. Például a kamera képből és a kormányszögből történik a hálózat betanítása sávkövetésre.

A másik fontos terület a megerösítéses tanulás, amely a klasszikus valószínüségi megközelítéséket próbálja meg ötvözni a mély neurális hálózatokkal. A megerősítéses tanulás alapelve, hogy az ágens megadott akciókat hajthat végre (cselekszik) a környezetében, amelynek hatására a környezet állapota megváltozik, és egy új állapotvektort ad vissza az ágensnek (3. ábra).

Emellett egy nagyon fontos tulajdonsága, hogy minden egyes lépésben egy skalár értéket, az ún. jutalmat is visszaadja az ágens részére. $\mathrm{Az}$ ágens célja, hogy a kumulált jutalomjelet hosszútávon maximalizálja. Emiatt a megerősítéses tanulásnál az állapotváltozók meghatározásán túl a jutalom definiálása is elsőd- 
3. ábra: Az ágens-környezet interakció

egy Markov döntési folyamatban [19]

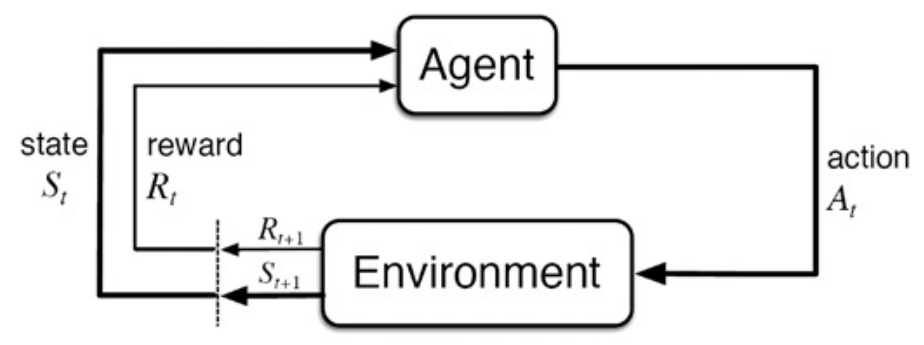

tervezésénél nem az ember által végrehajtott trajektóriát fog az ágens megtanulni, hanem egy közel optimálisat.

Érdekes példákat mutatnak erre a téma egyik vezető kutatóhelyének, a Deepmindnak az eredményei. A cég kutatói számítógépes és táblajátékokkal demonst-

leges fontosságú, hiszen ez határozza meg az optimalizációs célt. A környezetmodellezés jellemzően Markov döntési folyamattal történik, míg az ágens viselkedését egy ún. „policy” függvény írja le, amely az állapotok és akciók közötti összerendelést adja meg, így a cél az optimális „policy” meghatározása. Léteznek olyan módszerek is, amelyek nem közvetlenül próbálják meghatározni a „policy”-t, hanem az egyes állapotokhoz értékeket rendelnek hozzá („value” függvény) attól függően, hogy mekkora várható jutalmat lehet elérni az adott állapotból. Itt használják fel a kutatók a mélytanulás eredményeit, és a mély neurális hálózatokat függvényapproximátorként alkalmazzák az optimális „policy” és „value” függvények meghatározásához.

A legtöbb megerősítéses algoritmus nem ismeri a környezet modelljét („model-free”), csak a választható akciókat, az állapotvektort és a jutalmat. Ennek megfelelően véletlenszerü akciókkal kezdi működését és iteratív módon keresi az optimális megoldást. A keresés során fontos megtalálni a felfedezés (exploration) és kihasználás (exploitation) egyensúlyát, azaz mennyit használjon fel még a meglévő tudásból és mennyit próbálkozzon még véletlenszerüen? Itt a mérleg a tanulás hossza és a lokális optimumokban való beragadás között billeg. Ezek a módszerek alkalmasak lehetnek trajektória tervezésére [9], döntéshozásra, energia és egyéb optimumok megtalálására. Előnyük a felügyelt tanulással szemben, hogy nem kell megadni az optimális tanítómintákat, azok maguktól alakulnak ki. Így például egy trajektória rálják eredményeiket. A legutóbbi Alpha Go Zero algoritmusuk sakkban és Go-ban is az emberi játékosok, valamint a jelenlegi legjobb sakkgépek fölé emelkedett [10]. Ezt pedig úgy érte el, hogy előzetes ismeretek nélkül, pusztán magával játszva tanulta meg az optimális stratégiákat.

\section{HATÁSOK AZ INNOVÁCIÓ SZEKTORRA}

Az önvezető jármüvek, az elektromobilitás és a gyártásautomatizálás (Ipar 4.0) nagyon erős hatással van a jármüiparra. Az iparág komoly átalakuláson megy keresztül, amelynek köszönhetően megváltozik a mérnökök felé támasztott tudásigény. Erre természetesen a felsőoktatásnak is válaszolnia kell új képzések indításával és a hagyományos képzések modernizálásával. A BME Közlekedésmérnöki és Jármümérnöki Kara 2012-ben indította el a Jármümechatronika specializációt a BSc járműmérnök képzésen, amely folyamatosan pozitív visszajelzéseket kap a Magyarországon jelenlévő járműipari cégektől. Emellett 2018ban a Villamosmérnöki és Informatikai Karral közösen elindult az angol nyelvü Autonomous Vehicle Control Engineering MSc program, amely a legmodernebb tudás átadását tűzte ki célul a járműautomatizálás területén.

Nagyon erős katalizátor hatása lehet a Magyarországon épült ZalaZone autonóm jármüipari tesztpályának ( [11] és [12]). A létesítmény Zalaegerszeg közelében épül 250 hektáron. Területén a következő tesztek elvégzésére van lehetőség: 
- klasszikus járműdinamikai tesztek és validáció,

- teljesen integrált autonóm jármüves tesztek és validáció,

- környezet felépítésével (akadályok, jelzölámpák, forgalomirányítás, további jármüvek, gyalogosok, biciklisek),

- komplex vezetési és forgalmi szituációk,

- okos város elemek,

- tesztek és validáció a prototípus tesztelésétől a tömeggyártásig.

\subsection{Jog és etika}

A jogi és etikai háttér szorosan összefügg. Sok országban (többek között Magyarországon) bizonyos feltételekkel engedik az önvezető járművek tesztelését. Várhatóan szériában is pár éven belül az utakra kerülhetnek részleges önvezető funkciókkal rendelkező jármüvek, ezért szükséges a jogi szabályozást minél hamarabb kialakítani. Az egyik legfontosabb kérdés, hogy egy teljesen önvezető járműnek mi legyen az elsődleges biztonsági célja. Azaz egy elkerülhetetlen balesetnél a teljes kockázatot (a többi résztvevőt is beleértve) vagy csak a jármüben ülők kockázatát csökkentse. Társadalmi elvárás lehetne, hogy a teljes kockázatot mérlegelje, de az értékesítést ez jelentősen megnehezítené. A másik kérdés, hogy a jelenlegi közlekedési szabályokat figyelembe véve, mely szabályokat és milyen módon szeghetné meg az önvezető jármü. Például a záróvonal átlépés nem lehet teljesen szigorú, hiszen egy szabálytalan kikerülő manőver akár életet is menthet. Egy kisebb sebességtúllépés a forgalomtól függöen akár csökkentheti is a baleseti kockázatot. Ezek szabályozása alapvető fontosságú, hiszen a gyártóknak óriási felelősségük lesz, ezért tisztában kell lenniük a lehetőségeikkel. Végül a közvélemény előtt is ismertek a morális döntési kérdések. Például egy elkerülhetetlen baleset esetén kinek az élete ér többet. Szerencsére az önvezető járművek a várható szituációkat előre kiértékelik, és nagyon kis valószínűséggel állnak elő olyan speciális helyezetek, amelyekben minden választási lehetőség ugyanolyan kockázatokat rejt, így az a kérdés talán az adott helyzet kockázatelemzésével is megoldható.
Mindez rendkívül sok és összetett szoftverjogi, büntetőjogi, felelősségi és adatvédelmi kérdést vet fel a jogi oldalon. Emellett új alapokra kell helyezni a jármübiztosítások rendszerét is, hiszen a járművezetők már csak utasként, esetleg üzembentartóként fognak funkcionálni.

Ezek után szót kell ejteni az infrastruktúra helyzetéről. Ennek minősége és a karbantartási szintje kulcsfontosságú az autonóm járművek megfelelő működéséhez. A jelenlegi jelzések és azok ellenőrzései az emberi látásra alapoznak, nem pedig a gépi látásra. Ennek megfelelően sok olyan hiba és következetlenség előfordulhat, amely az embernek nem, azonban a gépnek problémát okoz. Az útburkolati jelek és közlekedési táblák szigorúbb szabványosítása fontos lenne. Fontos megemlíteni az ideiglenes eltereléseket és jelzéseiket. Itt gyakran találkozhatunk nem egyértelmű szituációkkal (4. ábra), amit a korábban már leírt módon intuitíven és kooperálva képesek az emberi jármüvezetők megoldani.

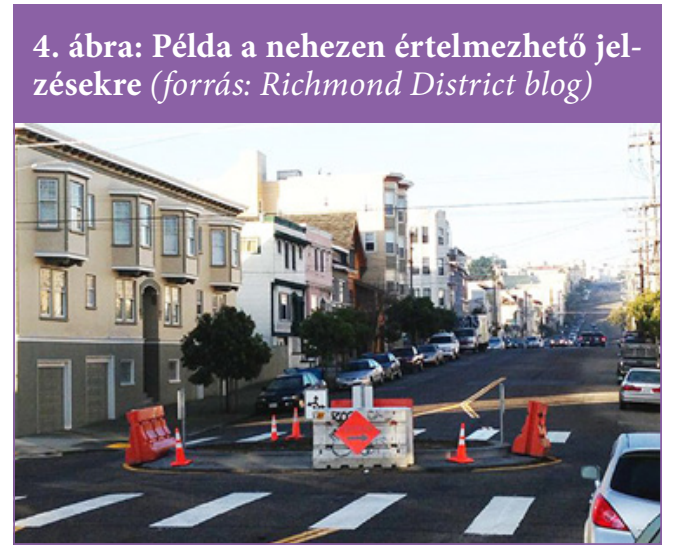

\section{ESETTANULMÁNY}

A következőkben egy olyan folyamatban lévő kutatásunkat mutatjuk be, amelynek során a megerösítéses tanulás segítségével próbálunk egy ágenst betanítani egy járműtrajektória optimális megtervezéséhez.

A feladat alapvető fontosságú a jármüirányítás és -automatizálás területén. Célja, hogy a járművet egy kezdeti dinamikai állapotból (pozíció, állásszög, sebesség, gyorsulás 


\section{5. ábra: Az ágens és a környezet kapcsolata}

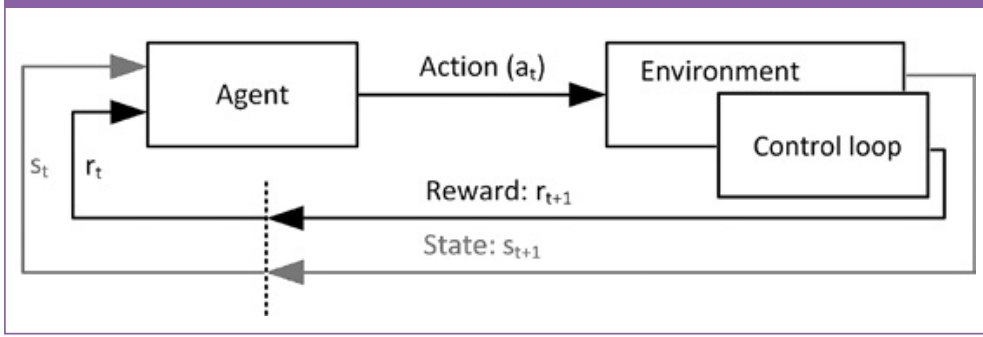

\subsection{Tanító környezet}

A trajektóriatervező megoldás valós jármüvön való futtatása elött, a DDPG ágenst egy mesterséges tanuló környezetben kell elhelyezni, ahol az próbálkozások sorozatával, tapasztalatot gyüjtve törekedni tud a jutalom

stb.) egy végállapotba vezessük. A feladat egy multikritériumos nemlineáris optimalizálási feladatként írható fel, ahol a szempontjaink az alábbiak:

- Pontosság

- Biztonság

- Megvalósíthatóság és robusztusság

- Kényelem - Testreszabhatóság

- Egyértelmü stratégia

- Algoritmus sebessége

Az elmúlt évek kutatásaiban a megerősítéses tanulás módszereivel folytattunk kísérleteket a feladat megoldására. Az általunk kifejlesztett algoritmus némileg különbözik a korábbiakban bemutatott általános megerősítő tanulási ciklustól, a módszer az 5. ábrán látható.

Minden epizódban az ágens megkapja a kezdeti és a kívánt jármủ végállapotot és - spline illesztéssel - generál egy trajektóriát a köztes pontok megadásával. A tervezett pályán a klasszikus hossz- és keresztirányú szabályozók végigvezetik a jármümodellt és a dinamikai paraméterek alapján értékelésre kerül a trajektória jósága. A jutalom értéket a kiértékelés után megkapja a tanuló ágens. Ezután a folyamat kezdődik elölről egy új epizóddal. A bemutatott folyamat egy-egy lépéses megerösítéses tanulás, aminél egy epizód csak egy lépésből áll és nem veszi figyelembe a következő állapotot. Ez az egyszerüsítés egyben redukálja a tanítási feladat komplexitását. Az állapot és az akciótér folytonos értékekből áll. Az alkalmazott DDPG (Deep Deterministic Policy Gradient) tanuló algoritmus [13] a kísérleteink alapján jól teljesít ezen feltételek mellett. maximalizálására. A szimulációs környezet a következő összetevőkből épül fel:

- teljesíthető trajektóriát generáló algoritmus,

- nemlineáris biciklimodell, dinamikus kerékmodellel,

- hossz- és keresztirányú szabályzó,

- jutalom függvény.

\subsection{Trajektóriatervezés}

A trajektóriatervező módszer bemenete a jármü állapota a kezdeti és a végpontban. Ezen információkat alapul véve a tanuló ágens meghatározza a trajektória köztes pontjait.

$\mathrm{Az}$ alábbiakban egy konkrét esetre mutatjuk be a tanítást, aminél a jármű sebessége konstans, $90 \mathrm{~km} / \mathrm{h}$. A kezdeti állapotvektor (1) tartalmazza a jármü pozícióját és állásszögét, amik a jármű koordináta-rendszerében értelmezett értékek. A (2) végállapot egyenletes eloszlású, véletlenszerü értékekből tevődik össze, amelyek maximumai kissé szélesebbek lehetnek mint a fizikailag megvalósítható tartomány (2). Túl sok minta a megvalósíthatatlan célvégállapotból meghosszabbíthatja a tanulási folyamatot, ezért ezt el kell kerülni, bár néhány hasznos lehet a határok megtanulásához.

$\left[\begin{array}{llll}x_{s} & y_{s} & \psi_{s} & v_{s}\end{array}\right]^{T}=\left[\begin{array}{llll}0 & 0 & 0 & 25 \mathrm{~m} / \mathrm{s}\end{array}\right]^{T}$

$\left[\begin{array}{c}x_{e} \\ y_{e} \\ \psi_{e} \\ v_{e}\end{array}\right]=\left[\begin{array}{c}3 * v_{\text {start }} \\ \operatorname{rand}\left(-y_{\max }, y_{\max }\right) \\ 0.1 * \psi_{\max }+\operatorname{rand}(0,1) * 1.3 * \psi_{\max } \\ v_{\text {start }}\end{array}\right]$

$R_{\min }=0.1207 * v_{\text {start }}{ }^{2.4736}$ 


$$
\begin{aligned}
& y_{\max }=R_{\text {min }}-\sqrt{R_{\text {min }}^{2}-x_{e}^{2}} \\
& \psi_{\text {max }}=-2 * \arctan \left(y_{e} / x_{e}\right)
\end{aligned}
$$

A tervezett trajektória egy dinamikai jármümodellel kerül validálásra. A megvalósítható végállapot tapasztalati képlettel határozható meg (3), amely megadja azt a legkisebb ívsugarat, amelyet egy átlagos jármü képes fix sebességgel teljesíteni normál körülmények között.

A kiindulási és a végállapot meghatározásakor az ágens meghatározza a két közbenső pont y koordinátáját, egyenlően elhelyezve a kezdeti és a végpont között az $\mathrm{x}$ koordináta mentén. A négy tartópont alapján egy spline kerül illesztésre, figyelembe véve a kezdő- és a véggradienst, amely megadja a kívánt állásszöget.

\subsection{Jármümodell}

A jármü viselkedésének pontos meghatározása érdekében egy dinamikus kerékmodellel rendelkező nemlineáris biciklimodell kerül felhasználásra. Ez a saját fejlesztésű modell jó eredményeket hozhat még dinamikus vezetési manőverek esetén is, de elég egyszerü ahhoz, hogy futási idejét és számitásigényét elfogadható szinten tartsa [14].

A több testből álló modell (6. ábra) magába foglalja a jármű alvázát és két rugalmasan kapcsolódó kerék reprezentálja az első és a hátsó tengelyt. A fő paraméterek a tömeg $\mathrm{m}$, az alváz tehetetlenségi nyomatéka $\Theta$, a hosszirányú távolságok a jármü tömegközéppontja és az első és a hátsó kerék középpontjai között $l_{f}$ és $l_{r}$, a jármü tömegközéppontjának magassága $h$, az első és a hátsó kerék tehetetlenségi nyomatékai $\Theta_{f}$ és $\Theta_{r}$, valamint sugarai $r_{f}$ és $r_{r}$. A kerékmodellek paraméterei szintén nagy befolyással bírnak, amelyek közül a legfontosabbak a súrlódási együtthatók $\mu_{f}$ és $\mu_{r}$, továbbá a Magic Formula csúszási görbék paraméterei $\mathrm{C}_{[f / \mathrm{f}],[\mathrm{x} / \mathrm{y}]}, \mathrm{B}_{[f / \mathrm{f}],[\mathrm{x} / \mathrm{y}]}$, $\mathrm{E}_{[f / r],[\mathrm{x} / \mathrm{y}]}$, amelyek befolyásolják az átvihető erő nagyságát az út és a gumiabroncsok között [15].

A modell bemenetei az első kerék kormányzási szöge $\delta$ (a hátsó kerék nem kormányzott) és a kerekekre ható hajtó $M_{d}$ és fékező $M_{b}$ nyomaték. A hajtónyomaték az első és a hátsó tengelyre oszlik meg $M_{[f / r], d}$ idő szerint változó eloszlási tényezővel $\xi_{M}$. A fékezési nyomaték esetén az ideális eloszlás $M_{[f r], b}$, amely fenntartja az azonos csúszásokat. Az alváz képes mozogni hosszirányban $x$, keresztirányban $y$ és forogni $\psi$ a függőleges tengelye körül. A kerekek csak a saját vízszintes tengelyük körül forognak $\phi_{f}$ és $\phi_{n}$ a hossz- és oldalcsúszásokat $s_{[f / r],[x / y]}$ dinamikusan modellezik.

A kerékmodell lehetővé teszi explicit ODEmegoldók használatát, közepes időlépéssel, ami $1 \mathrm{~ms}$ körül alakul.

\subsection{Hossz- és oldalirányú szabályzók}

A jármü pálya mentén történő végigvezetéséhez hossz- és oldalirányú szabályzókat implementáltunk. Az epizód elején a jármü a kez-

\section{6. ábra: Jármümodell}
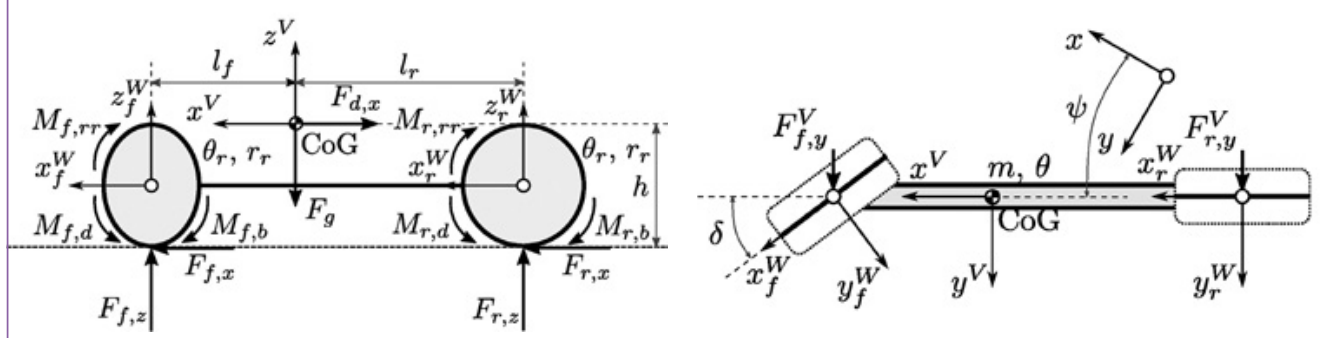
deti állapot szerinti fix sebességre gyorsít fel egy inicializálási szakasz során. A trajektórián való végighaladás csak ezután kezdődik meg. A sebességtartást egy egyszerü PID szabályzó hatékonyan valósítja meg. Az oldalirányú szabályozásért a Stanley módszer [16] felelős.

$$
\delta=-\left(\psi+\arctan \left(k * \frac{y}{v}\right)\right)
$$

ahol $\psi$ a szöghiba az első tengelynél, $y$ az oldalirányú hiba az első tengelynél, $v$ a jármü sebessége (az első tengelyen számolva, aminek iránya párhuzamos az első kerékkel) és $k$ az erősítési tényező.

\subsection{Jutalomszámítás}

Az ágens minden tanítási lépésben kap egy állapotvektort a trajektória kezdeti feltételeivel és meghatároz akciókat, amik ebben az esetben a köztes pontok. A jutalom érték meghatározásához a jármüvet a hossz- és keresztirányú szabályzó vezeti végig a tervezett pályán. A tanítási folyamat minden egyes epizódja addig tart, amíg a jármű el nem éri a pálya végét, vagy egy kritikus feltétel meg nem állítja.

A jutalom függvény meghatározásakor a következő kritikus feltételeket állapítottuk meg:

- Az oldalirányú távolság hiba nagyobb, mint 10 méter.

- A hossz- vagy az oldalirányú slip nagyobb, mint 0,1 .

- A maximum lépésszám nagyobb, mint 2500.

- A legyezési szöghiba nagyobb, mint 0,2 radián.

A kritikus feltételek mellett a lépésenként összegzett slip és az ellenőrző pontokban nézett, pozíció szerint súlyozott oldalirányú és szöghiba alapján kerül kiértékelésre az ágens teljesítménye. Az epizód jutalom ezen három komponens súlyozott összegéből adódik:

$\mathrm{R}_{\text {episode }}=\mathrm{s}_{\mathrm{w}} * \mathrm{R}_{\text {slip }}+\mathrm{d}_{\mathrm{w}} * \mathrm{R}_{\text {dist }}+\mathrm{a}_{\mathrm{w}} * \mathrm{R}_{\text {angle }}$

A környezet 10 darab, a trajektória mentén egyenlően elosztott ellenőrző pontot $(c p)$ definiál.
A távolság $\left(R_{\text {dist }}\right)$ és a szög $\left(\mathrm{R}_{\text {angle }}\right.$ jutalmak az ellenőrzőpontoknál, a slip jutalom $\left(R_{\text {slip }}\right)$ minden időlépésben kiszámításra kerül. A részjutalmak a $[0,3]$ tartományba esnek és a következőképpen történik a meghatározásuk.

$$
\begin{aligned}
& R_{\text {slip }}=3-\sum_{\text {step }=1}^{\max s t e p}-a b s\left(\max \left(s_{[f / r],[x / y]}\right)\right) / 10 \\
& R_{\text {angle }}=3-\sum_{c p=1}^{10}-a b s(\psi) * 2 * \text { pos } \\
& R_{\text {dist }}=3-\sum_{c p=1}^{10}-a b s(y / 3) * 2 * \text { pos }
\end{aligned}
$$

Ahol $\psi$ az első tengelynél vett szöghiba, $y$ az oldalirányú hiba és pos a jármű pozíciója a trajektória mentén. Az értéke 0 a kezdeti pozícióban és 1 a végén. A kezdeti érték és a képletek tapasztalati úton kerültek meghatározásra. Amennyiben egy kritikus feltétel bekövetkezik, az epizódnak vége és az ágens negatív jutalmat $(\mathrm{R}=-10)$ kap. Ha az ágens sikeresen végigért a pályán, akkor a (7) szerinti jutalomban részesül.

\subsection{Valós teszt}

A szimulációs környezetben végzett tanítások eredményének validálása után, a kifejlesztett rendszer tesztelésre került valós jármüvel tesztpályás környezetben a zalaegerszegi tesztpályán. A következő fejezet a tesztkörnyezetet részletesen bemutatja.

\subsubsection{Jármü}

A tesztekhez használt jármú egy Smart Fortwo (7. ábra), amely autonóm jármüfunkciók tesz-

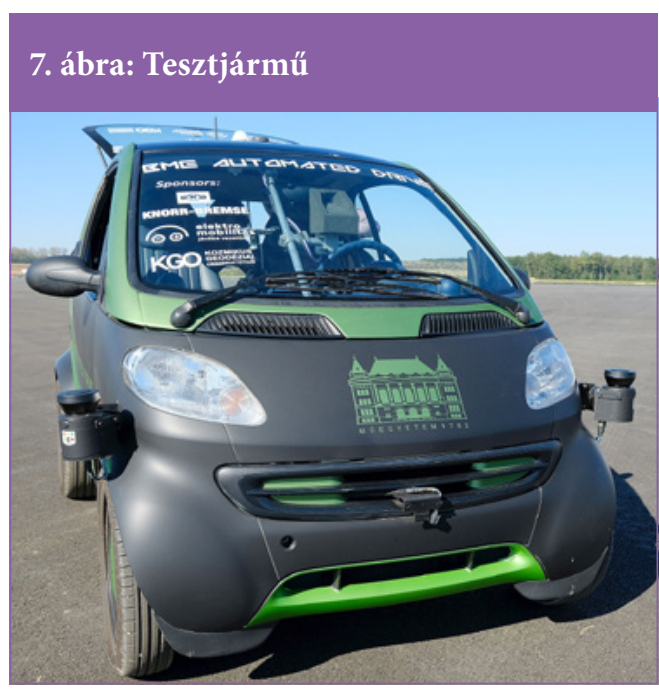


telése és demonstrálása céljából nagyrészt átalakításra került, ezért a jármű nem közlekedhet közutakon.

A Smart egy kézi működtetésü elektromechanikus sebességváltóval van felszerelve. A váltókart egyedi tervezésű vezérlőegység váltja ki, amely lehetővé teszi a sebességváltást CAN buszon keresztül. A nyomatékparancs egy analóg feszültségérték, amit a gázpedál megkerülésével a dSPACE Autobox vezérlőegység analóg kimenetével állít elö. A fékpedál egy lineáris aktuátorral aktiválható. A kormánymű forgatásáért egy DC szervómotor felelős. A jármü gyárilag CAN busszal szerelt, amit további hárommal bővítettek ki a tesztrendszer számára.

A tesztjármüvünket több érzékelővel is felszerelték. A szélvédő alatt van egy autóipari kamera-modul, amely többek közt képes magas szintű sáv- és objektuminformációt szolgáltatni. Két különböző típusú precíziós GPS modul végzi a helymeghatározást. Előre és hátra autóipari radarok kerültek beépítésre. Az első fényszórók magasságában két, nagy pontosságú, 2D lidar kapott helyet [17].

\subsubsection{Tesztelés menete}

A megerősítéses tanuló algoritmus validálására egy Python alapú teszt környezetet fejlesztettek ki. A cél, hogy a jármű képes legyen a betanított neurális hálózat által generált pályán végighaladni, miközben az érzékelők adatait eltárolja. A teszt rendszer hierarchikus felépítésü (8. ábra). A dSPACE Autobox eszköz felelős az alacsony szintű szabályozásért kormányszög és sebesség parancsok végrehajtásával. A Python alapú algoritmus egy Vector CAN eszköz segítségével kapcsolódik a jármü buszrendszerére. Az Autoboxot, a GPS-t és az inerciális szenzort erre a CAN hálózatra kötötték.

A teszt elején a teljes tervezési tartomány lefedése érdekében teszteseteket definiáltunk, amelynek során kanyarodási és kikerülési manőverereket teljesített a jármü különböző sebességekkel. A teszt elejétől kezdve a tervezett trajektória, a szabályzó paraméterek és a CAN forgalom mentésre kerül. A szimulációban kifejlesztett hossz- és oldalirányú szabályzók irányítják a járművet a valós teszteknél.

\section{8. ábra: Tesztarchitektúra}

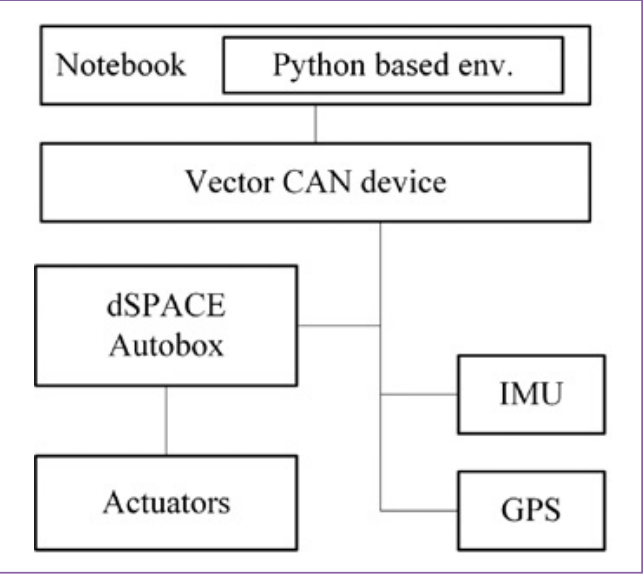

A teszteket a dinamikai platformon (9. ábra) hajtottuk végre. Ez egy 300 m átmérőjű ultra sík aszfalt felület egy 760 és egy 400 m hosszú gyorsító sávval és $20 \mathrm{~m}$ széles FIA (International Automobile Federation) bukótérrel.

\subsubsection{Teszteredmények}

A tesztkörnyezet megvalósításán túl meg kellett tervezni a teszteseteket a valós járművön való futtatáshoz. Biztonsági okokból a teszteket maximum $40 \mathrm{~km} / \mathrm{h}$ sebességgel hajtottuk végre, miközben egy soför ült a jármüben. Teszteket végeztünk 20, 30 és $40 \mathrm{~km} / \mathrm{h}$ sebességgel. A kifejlesztett tanító környezetben a jármü konstans sebességgel haladt, ezért különböző tanításokat kellett indítani az eltérő sebességek esetében. A DDPG alapú tanuló ágens az 1. táblázat szerinti eredményeket érte el a tanítás során. Minden tanítás sikeresen konvergált egy magas jutalom értékre. Minden esetben az egyenlően elosztott jutalom súlyok vezettek a legjobb eredményre.

A neurális hálózat struktúrája és a zajparaméterek minden tanítási esetben azonosak voltak (2. táblázat).

A kifejlesztett módszer teljesítményét a legnehezebb manővernél, a legnagyobb sebességgel mutatjuk be. A 10. ábra egy $40 \mathrm{~km} / \mathrm{h}$ sebességgel végrehajtott kikerülési manővert mutat be. A piros vonal jelöli a tervezett trajektóriát és a kék a bejárt utat. A szaggatott vonal a cél ol- 


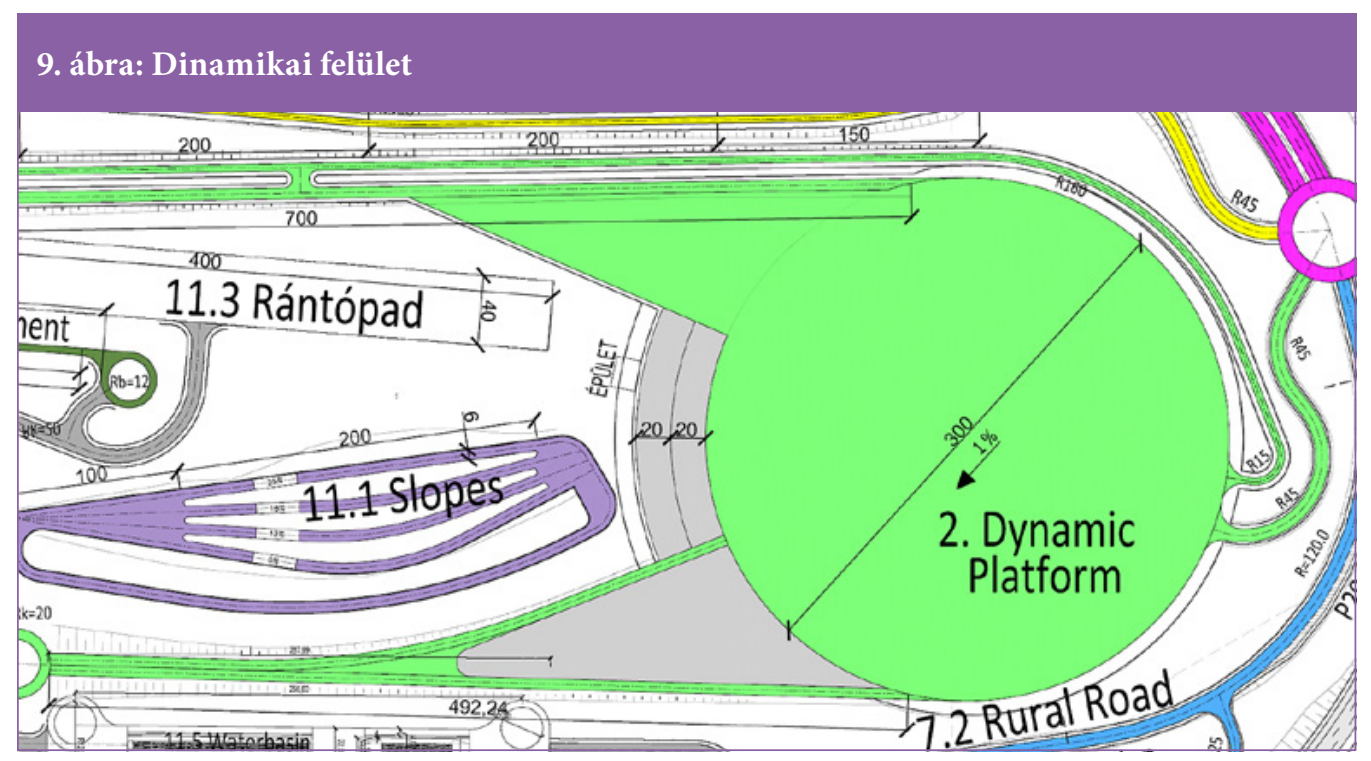

1. táblázat: Tanítási teljesítmény
\begin{tabular}{|c|c|c|c|}
\hline Sebesség & $\begin{array}{c}\text { Max. Q érték } \\
\text { átlaga }\end{array}$ & Epizódszám & Tanítási idő \\
\hline $20 \mathrm{~km} / \mathrm{h}$ & 2.707 & 26840 & $8 \mathrm{~h} 31 \mathrm{~m}$ \\
\hline $30 \mathrm{~km} / \mathrm{h}$ & 2.718 & 50000 & $20 \mathrm{~h} 11 \mathrm{~m}$ \\
\hline $40 \mathrm{~km} / \mathrm{h}$ & 2.732 & 50000 & $21 \mathrm{~h} 27 \mathrm{~m}$ \\
\hline
\end{tabular}

\begin{tabular}{|c|c|}
\hline \multicolumn{2}{|c|}{ 2. táblázat: Hiperparaméterek } \\
\hline \multicolumn{2}{|l|}{ Actor hálózat } \\
\hline Tanulási ráta $(\alpha)$ & 0.0001 \\
\hline Minta memória méret & 64 \\
\hline Rejtett teljesen összekapcsolt rétegek & {$[128,100,64]$} \\
\hline Aktivációs függvény & relu \\
\hline Kimeneti szorzó & {$[2,4]$} \\
\hline \multicolumn{2}{|l|}{ Critic hálózat } \\
\hline Tanulási ráta $(\alpha)$ & 0.001 \\
\hline Discount factor $(\gamma)$ & 0.99 \\
\hline Rejtett teljesen összekapcsolt rétegek & {$[128,64]$} \\
\hline Aktivációs függvény & relu \\
\hline \multicolumn{2}{|l|}{ Ornstein-Uhlenbeck paraméterek } \\
\hline$(\mu)$ & {$[0,0]$} \\
\hline$(\sigma)$ & 0.3 \\
\hline$(\theta)$ & 0.15 \\
\hline
\end{tabular}

daltávolságot ábrázolja. Látható, hogy a jármü elfogadható hibával képes végrehajtani a manővert. A pálya végrehajtása során az átlagos távolsághiba $0,3051 \mathrm{~m}$, az átlagos szöghiba 0,0415 fok. A jármüben ülve komfortos volt a pálya végrehajtása.

\section{0. ábra: Trajektória}

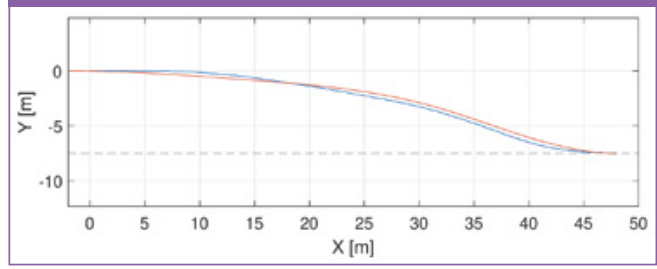

Ahogy korábban láthattuk a rendszer jutalmazza a slip alacsony értéken tartását és a kis szög és távolsághibát a tanítás közben. A slip arányos az oldalgyorsulással, ami a 11. ábrán látható. A maximum gyorsulás érték $0,5 \mathrm{~m} / \mathrm{s}^{2}$ körül alakult, ami teljesíti az elvárásokat.

\section{1. ábra: Oldalgyorsulás}

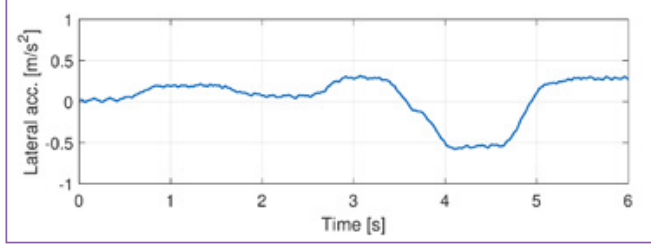




\section{5. ÖSSZEFOGLALÁS}

Az elözőekben röviden bemutattuk a közlekedés és a gépi tanulás kapcsolatát, valamint a járműipar átalakulását. Vázoltuk a várható hatásait az innovációs szektorra, valamint felvetettük a megoldandó jogi, etikai és infrastrukturális kérdéseket. Ezt követően részletesen bemutattunk egy esettanulmányt a gépi tanulás jármüirányítási célú alkalmazásról, valamint a ZalaZone tesztpálya kutatási célú felhasználásáról.

Megállapítható, hogy a gépi tanulás alkalmazása gyökeresen át fogja alakítani a közlekedésszervezést és irányítást, valamint a jármüvek tervezését és gyártását. Különösen kiemelt téma napjainkban az önvezetés. Leszögezhetjük azonban, hogy egy európai szintű teljes körü önvezetésre képes jármüre még évtizedeket várnunk kell. Azonban folyamatosan jelennek meg az egyre fejlettebb, magasan automatizált jármüvek az utakon, amelyek már részleges önvezető funkciókkal rendelkeznek. Az egyre jobban automatizált járművek, a jármümegosztó szolgáltatások és a kapcsolódó innovatív informatikai szolgáltatások mindenképpen nagyobb biztonságot és energiahatékonyabb közlekedést eredményeznek a közutakon. Azonban még nagyon sok feladat vár megoldásra mind a járműirányítás, mind a kapcsolódó tudományágakon belül, továbbá a döntéshozóknak is fel kell készülniük az új kihívásokra.

\section{FELHASZNÁLT IRODALOM}

[1] P. Gáspár, Z. Szabó, J. Bokor és B. Németh, Robust Control Design for Active Driver Assistance Systems: A Linear-ParameterVarying Approach, Springer International Publishing, 2017. DOI: http://doi.org/djzk

[2] O. Sename, P. Gáspár és J. Bokor, Robust Control and Linear Parameter Varying Approaches, Berlin Heidelberg: SpringerVerlag, 2013. DOI: http://doi.org/djzm

[3] Waymo, „Waymo Safety Report: On The Road to Fully Self-Driving," 2017.. [Online]. Available: https://waymo.com/safetyreport/.

[4] Crash Research \& Analysis, Inc., „Special crash investigations: On-site automated driver assistance system crash investigation of the 2015 Tesla model S 70D (Report No. DOT HS 812 481)," National Highway Traffic Safety Administration, Washington, DC, 2018..

[5] S. Russel és P. Norvig, Mesterséges Intelligencia: Modern megközelítésben, Budapest: Panem kft., 2005.

[6] T. Mitchell, Machine Learning, McGraw Hill, 1997.

[7] F. Rosenblatt, „The Perceptron--a perceiving and recognizing automaton," Report 85460-1, Cornell Aeronautical Laboratory, 1957.

[8] C. B. Csáji, Approximation with Artificial Neural Networks, Eindhoven, 2001.

[9] F. Hegedüs, T. Bécsi, S. Aradi és P. Gáspár, „Model Based Trajectory Planning for Highly Automated Road Vehicles," in IFAC World Congress: IFAC-PapersOnLine, Toulouse, Franciaország, 2017. DOI: http://doi.org/djzn

[10] D. Silver, J. Schrittwieser, K. Simonyan, I. Antonoglou, A. Huang, A. Guez, T. Hubert, L. Baker, M. Lai, A. Bolton, Y. Chen, T. Lillicrap, F. Hui, L. Sifre, G. v. d. Driessche, T. Graepel és Demis, „Mastering the game of Go without human knowledge," Nature, \%1. kötet550, pp. 354-359, 2017. DOI: http://doi.org/gcsmk9

[11] Z. Szalay, Z. Hamar és P. Simon, „A multilayer autonomous vehicle and simulation validation ecosystem axis: Zalazone," Advances in Intelligent Systems and Computing, \%1. kötet867, pp. 954-963, 2019. DOI: http://doi.org/djzp

[12] Z. Szalay, T. Tettamanti, D. Esztergár-Kiss, I. Varga és C. Bartolini, „Development of a test track for driverless cars: Vehicle design, track configuration, and liability considerations," Periodica Polytechnica Transportation Engineering, \%1. kötet 46, pp. 29-35, 2018. DOI: http://doi.org/dktg

[13] T. P. Lillicrap, J. J. Hunt, A. Pritzel, N. Heess, T. Erez, Y. Tassa, D. Silver és D. Wierstra, „Continuous control with deep reinforcement learning," arXiv preprint arXiv:1509.02971, 2015.

[14] F. Hegedűs, T. Bécsi, S. Aradi és P. Gáspár, „Model Based Trajectory Planning for Highly Automated Road Vehicles," IFACPapersOnLine, \%1. kötet50, \%1. szám1, pp. 
6958-6964, 2017. DOI: http://doi.org/djzn

[15] H. B. Pacejka, Tire and Vehicle Dynamics (Third Edition), Oxford: ButterworthHeinemann, 2012.

[16] S. Thrun, M. Montemerlo, H. Dahlkamp, D. Stavens, A. Aron, J. Diebel, P. Fong, J. Gale, M. Halpenny, G. Hoffmann, K. Lau, C. a. P. M. Oakley és e. al., Stanley: The robot that won the DARPA Grand Challenge, Wiley, 2006. DOI: http://doi.org/c52vnf

[17] T. Bécsi, S. Aradi, Z. Szalay és V. Tihanyi,
„2D lidar-based localization for highly automated parking in previously mapped environment," in 34th International Colloquium on Advanced Manufacturing and Repairing Technologies in Vehicle Industry, Budapest, 2017.

[18] A. Gibson és J. Patterson, Deep Learning, O'Reilly Media, Inc., 2017.

[19] R. S. Sutton és A. G. Barto, Reinforcement Leaning: An Intorduction, The MIT Press, 2017.

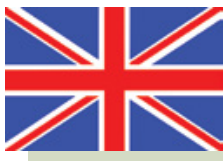

\section{The role and effects of machine learning in transport}

This article addresses the present and the predictable future role of artificial intelligence, and in particular machine learning, in transport. It briefly describes trends and changes in transport and vehicle development. It introduces the basics and types of machine learning, an important area of artificial intelligence. The article gives a brief overview of the impact of changes in the automotive industry in the area of the innovation sector, including higher education, and developments in Hungary such as the ZalaZone Automotive Test Track. It then summarizes the relevant legal and ethical issues, focusing on autonomous vehicles. A longer chapter discusses an ongoing domestic research which conducts experiments in the area of trajectory design using reinforcement learning methods. This gives insight into the details of the requirements and problems that arise, as well as a possible solution through machine learning. Finally, several results of the tests carried out at the ZalaZone test track are presented.

\section{Die Rolle und die Aus- wirkungen des maschinel- len Lernens im Verkehr}

Dieser Artikel befasst sich mit der gegenwärtigen und zukünftigen Rolle der künstlichen Intelligenz und insbesondere des maschinellen Lernens im Verkehr und behandelt kurz die Trends und die Veränderungen im Verkehr und in der Fahrzeugentwicklung. Es werden die Grundlagen und Arten des maschinellen Lernens - eines wichtigen Bereichs der künstlichen Intelligenz - vorgestellt. Danach folgt ein kurzer Überblick über die Auswirkungen der Veränderungen in der Automobilindustrie auf den Innovationssektor, einschließlich des Hochschulwesens, und über die Entwicklungen in Ungarn wie das ZalaZone Versuchsgelände für die Autoindustrie. Anschließend werden die relevanten rechtlichen und ethischen Fragen zusammengefasst, wobei der Schwerpunkt auf die autonomen Fahrzeuge gesetzt wird. Ein längeres Kapitel befasst sich mit der laufenden ungarischen Forschung im Bereich der Trajektoriengestaltung, wobei die Methoden des verstärkten Lernens verwendet werden. Auf diese Weise erhält der Leser einen Einblick in die Details der auftretenden Anforderungen und Probleme sowie in ihre mögliche Lösung mit der Hilfe des maschinellen Lernens. Es werden schließlich einige Ergebnisse der auf der ZalaZone-Teststrecke durchgeführten Versuche beschrieben. 